\title{
Great challenges in volcanology: how does the volcano factory work?
}

\author{
Valerio Acocella * \\ Dipartimento di Scienze, Università Roma Tre, Roma, Italy \\ *Correspondence: acocella@uniroma3.it \\ Edited by: \\ Agust Gudmundsson, Royal Holloway University of London, UK \\ Reviewed by: \\ Marco Neri, Istituto Nazionale di Geofisica e Vulcanologia, Italy \\ Ines Galindo Jimenez, Geological Survey of Spain, Spain
}

Keywords: volcanoes, magma rise, magma emplacement, volcano unrest, eruption forecast

\section{INTRODUCTION}

Scientists are asked to describe and understand the complex behavior of natural processes. This is often done in difficult conditions, with instruments detecting specific indicators and providing limited datasets to satisfy knowledge and imagination. Despite these limitations, many studies have been able to provide unprecedented understanding of different processes in nature, albeit often under specific (i.e., simplified) conditions. A progressively more quantitative approach has been often obtained exploiting the latest technological improvements available.

The study of volcanic, or more generally, magmatic processes well exemplifies these conditions and progression (Figure 1). Qualitative reports of how volcanoes erupt date back to thousands of years, as the description of the $79 \mathrm{AD}$ Vesuvio eruption from Pliny the Younger; however, most of our qualitative and quantitative understanding of the volcano factory and its various indicators has been definitely achieved in the frame of the technological boost of the last decades.

Certainly, the tremendous improvement of the monitoring system of active and erupting volcanoes has allowed detecting many changes in the geophysical, geodetic and geochemical behavior before, during and after eruptions (e.g., Lowenstern et al., 2006; Sigmundsson et al., 2010; Chiodini et al., 2012). As a result, a significant amount of data has been collected on a reasonable amount of active volcanoes worldwide, and it is in general possible to assign some physical or chemical meaning to many detected changes. This knowledge is also crucial to define when a volcano enters a phase of deviation from its baseline, or unrest, which may culminate in an eruption and to forecast any impending eruption. The understanding of the processes occurring within volcanoes, ultimately leading to the geophysical, geodetic and geochemical changes detected at the surface, is supported by analytical, numerical, and experimental models (e.g., Cayol et al., 2000; Gudmundsson, 2006; Caricchi et al., 2007; Ruch et al., 2012). Modeling has reached a relatively sophisticated stage, allowing understanding otherwise inaccessible and/or long-lasting $2 \mathrm{D}$ and, to a lesser extent, 3D processes. Similarly crucial to understand the mean to longerterm behavior of volcanoes are many field and petrological-geochemical studies, supported by dating techniques (e.g., Gravley et al., 2007; Thordarson and Larsen, 2007; Collins et al., 2009; Wilson and Charlier, 2009; Corsaro et al., 2013). In particular, field studies prove fundamental in reconstructing the eruptive history of a volcano, including the eruption location, type, size and frequency; petrological and geochemical studies provide an invaluable amount of information on the processes and times characterizing the formation of the magma, its rise and emplacement within the crust, including mixing, mingling, crustal assimilation, and fractionation.

These approaches have allowed reaching a dramatic advancement in our understanding of volcanoes. An overview of the major improvements in volcanology in the last decades is beyond the scope of this contribution. For facts, one can refer to the comprehensive, detailed and essential overview of Cashman and Sparks (2013). This includes many of the important studies on the emplacement (formation of magma chambers), rise (eruption triggers, dike propagation), and eruption of magma (conduit construction and evolution, magma rheology and fragmentation, eruptive styles). The described amount of research underlines the impressive efforts made by the volcanological community in considering and analyzing the several complex evolutionary stages of a magma within the volcano factory, from its generation to its eruption. Even though the reached level of knowledge may not unravel the many questions behind the volcano factory, it certainly provides a robust platform to test hypotheses and plan more advanced and sophisticated studies.

Indeed, despite the important achievements, modern volcanology still has to fully define and understand several major processes, involving different topics and approaches, and resulting in likewise challenges for the future. Here the first-order processes, or challenges for volcanology, are summarized in an ideal journey from the deepest to the shallowest portions of the volcano factory (Figure 2). Many of these processes may be unraveled not only by observations on volcanoes on Earth, but also on extraterrestrial volcanoes, including those on Venus, Mars and Io. While studies on terrestrial volcanism provide the key to understand also extraterrestrial volcanism, it is likewise expectable that observations on adequately imaged volcanic edifices from Mars and Venus allow to better define volcanic processes on Earth. 


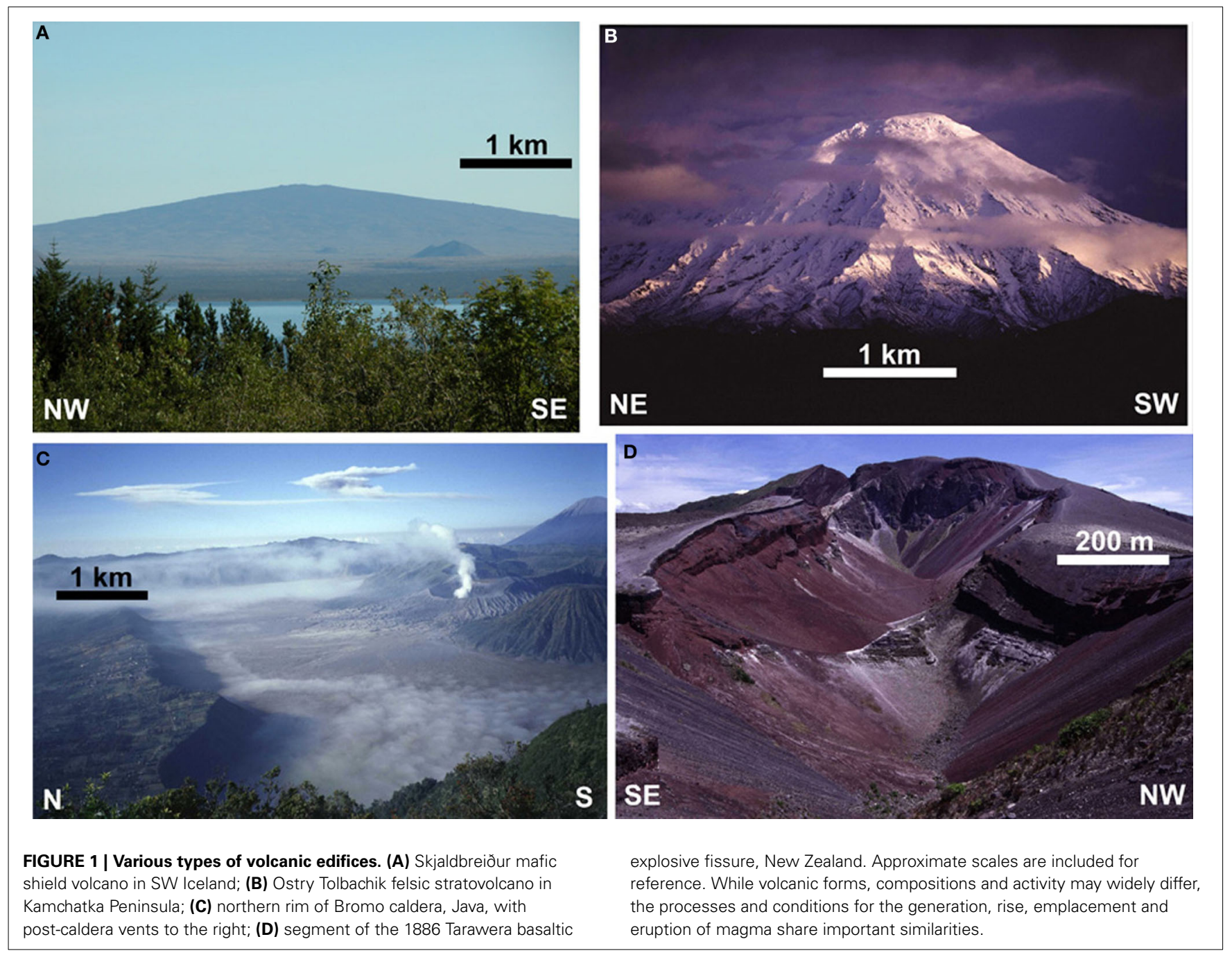

\section{CHALLENGE 1: FORMATION AND DEVELOPMENT OF MAGMATIC RESERVOIRS}

Many of the questions we ask ourselves on the behavior of active volcanoes at the surface inevitably lead to the dynamics of the underlying magma reservoirs, often highlighting the limited knowledge on the deeper processes. For example, despite field and theoretical studies on the mechanical and thermal constraints for the generation of magma reservoirs, we still do not have a clear understanding on why and how magma may emplace and accumulate within the crust. Certainly, density contrasts between magma and the host rock, as well as physical (including elasticity, temperature, pre-existing discontinuities) contrasts within the host rock, may play a fundamental role in the formation and development of magma reservoirs; however, other parameters, as magma flux and mixing, hydrothermal alteration, crustal rheology and regional tectonic conditions may be also important (e.g., Kavanagh et al., 2006; Valentine and Krogh, 2006; Famin and Michon, 2010; Gudmundsson, 2011; Leuthold et al., 2012). Which of these processes, and under which physical conditions, is more likely to control magma emplacement within the crust? Conditions and thresholds should be investigated, also in a comparative way, to define hierarchies.

In addition, recent studies highlight episodic and rapid magma accumulation and remobilization, also immediately before super-eruptions, involving tens of $\mathrm{km}^{3}$ of magma (Druitt et al., 2012; Parks et al., 2012; Cooper and Kent, 2014); in some cases, as at Toba caldera (Sumatra), these processes may involve magma volumes up to a thousand of $\mathrm{km}^{3}$, characteristic of super-volcanoes (Vazquez and Reid, 2004). At the topmost of the scale are the Large Igneous Provinces, erupting large quantities of basaltic magma in geologically short periods, closely correlating with major changes in oceanic and atmospheric chemistry and whose origin is still poorly understood (Saunders, 2005). How may these significant amounts of magma from supervolcanoes and Large Igneous Provinces be efficiently stored in the crust? Do they follow the same emplacement processes as those of the magma feeding much smaller eruptions?

In addition to the formation and growth, it is also crucial to better understand which factors control the dynamic behavior of the magma reservoirs. This brings us to another question: which 


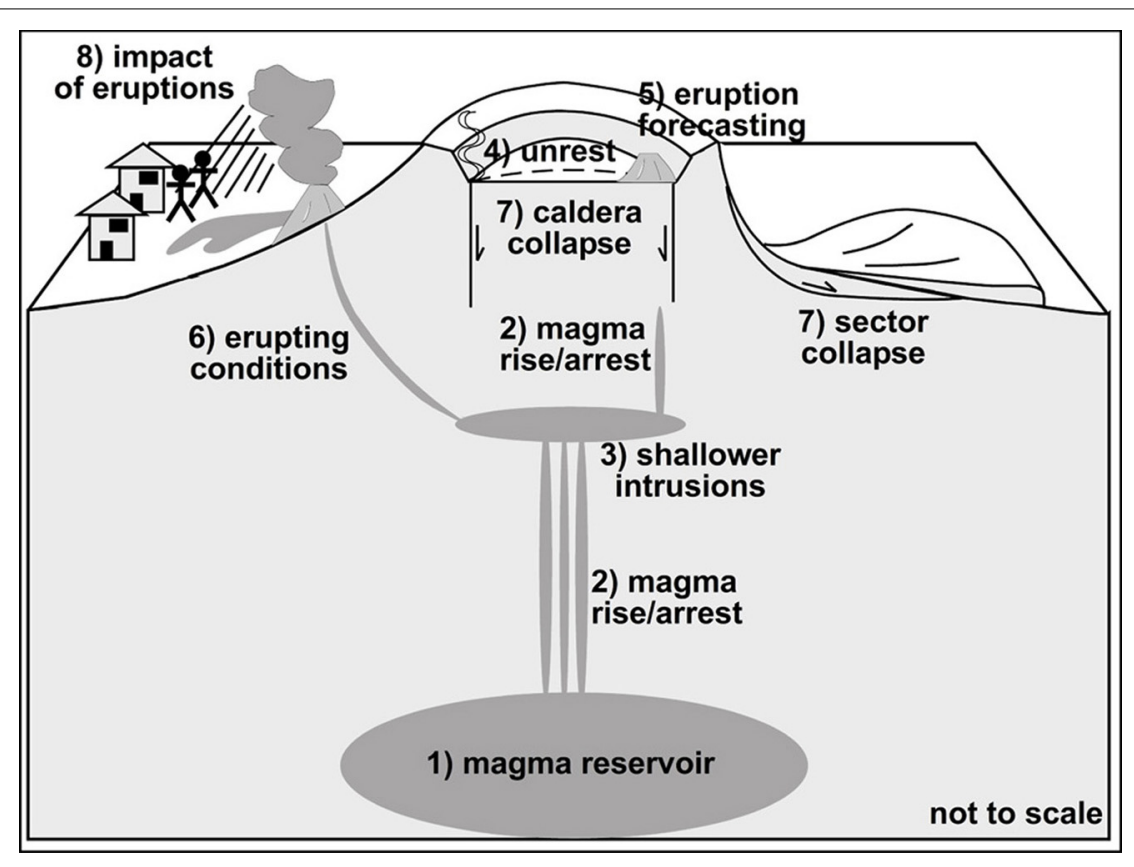

FIGURE 2 | The main theoretical and applied challenges associated with the volcano factory, involving the emplacement, rise, and eruption of magma (not to scale). These are the most crucial first-order processes Frontiers in Volcanology aims to detect and understand. See text for details.

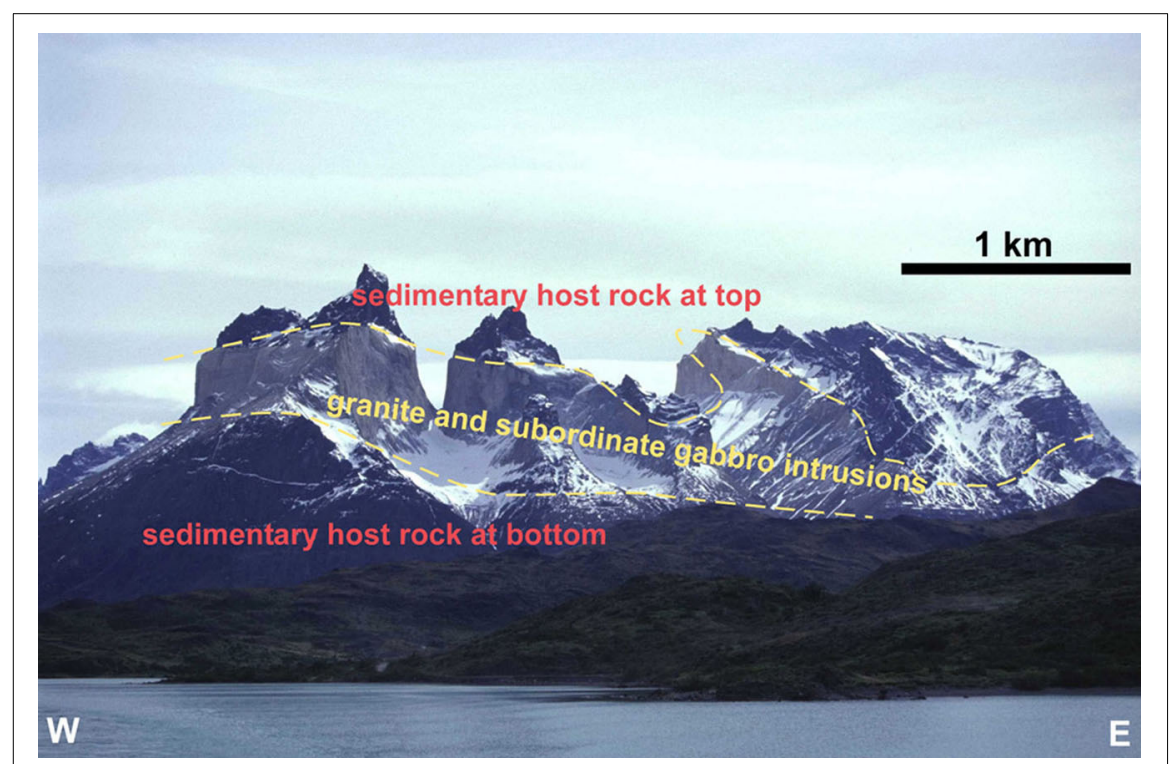

FIGURE 3 | Picture of the eroded Torres del Paine laccolith, in the Chilean Patagonia (yellow dashed line underlines its approximate boundaries). Approximate scale is included for reference. The $12.5 \mathrm{Ma}$ old laccolith consists of multiple bimodal intrusions of granite and gabbro, with a volume of $\sim 88 \mathrm{~km}^{3}$ emplaced in $\sim 160 \mathrm{ka}$ (Leuthold et al., 2012). Examples like this are ideal analogs to understand the formation, development and dynamics of present-day magma chambers below active volcanoes.

conditions must be met to have inflation of a reservoir, or magma propagation outside it? An important consequence of magma reservoir dynamics may be resurgence, or the uplift of portions of calderas up to some $\mathrm{km}$. While we have many studies and models for caldera formation, our knowledge on resurgence, that is the opposite process, is still definitely limited, with few recent studies and models (Vezzoli et al., 2009; Kennedy et al., 2012; Merle et al., 2013). Certainly, the causes and conditions for resurgence need to be further investigated, and many questions may find an answer in better understanding the longer-term dynamic behavior of magma reservoirs. For possible answers on the development of magma reservoirs, we should definitely learn more from the study of exposed plutons, merging the efforts of the volcanological community with those of the community investigating intrusions and thermo-metamorphic processes (Figure 3).

\section{CHALLENGE 2: PROPAGATION AND ARREST OF MAGMA}

Magma rises in the upper crust through dikes; dikes are also responsible for feeding most eruptions, largely independently of the composition of magma. The shallow conduit of volcanoes may be imaged as a cluster of dikes, as confirmed by recent drilling in the conduit zone of Unzen volcano, consisting of a hundreds of $m$ wide dike zone (Sakuma et al., 2008). Dikes may reach lengths of tens of $\mathrm{km}$, delivering magma and feeding eruptions for significant distances also outside volcanoes. However, dikes may often become arrested of the composition of magma. The shallow conduit of volcanoes may be imaged as a cluster of dikes, as confirmed by recent drilling in the conduit zone of Unzen volcano, consisting of a hundreds of $\mathrm{m}$ wide dike zone (Sakuma et al., 2008). Dikes may reach lengths of tens of $\mathrm{km}$, delivering magma and feeding eruptions for significant distances also outside volcanoes. However, dikes may often become arrested and not generate any eruption (e.g., Gardine et al., 2011). Several recent studies highlight the extremely rapid transfer of magma, up to $\mathrm{m} / \mathrm{s}$, from the mantle or shallower levels, even for rhyolitic compositions and in apparently unfavorable tectonic conditions (Castro and Dingwell, 2009; Ruprecht and Plank, 2013). These results, coupled with those highlighting rapid recharge times within magmatic reservoirs, are changing the perspective on the rates of magma accumulation and transfer, with important implications also for volcanic hazard. 
As dikes are responsible for magma transfer within the crust and volcanic edifices, understanding the conditions for their propagation or arrest, as well as their propagation path, is one of the most important challenges, for both theoretical and applied volcanology (Figure 4). Under which conditions does a dike transfer magma to shallower levels? Why most dikes stall at depth, without feeding eruptions? Several mechanisms have been proposed to control dike propagation, including magma pressure, buoyancy, composition, and volatiles, topography and physical contrasts (rigidity, density, pre-existing discontinuities) within the host rock (e.g., Pinel and Jaupart, 2004; Aoki et al., 2009; Geshi et al., 2010; Taisne et al., 2011; Maccaferri et al., 2014). However, these mechanisms remain largely theoretical and their direct applicability or frequency of occurrence in nature has not been really tested. As a consequence, there is poor definition of the hierarchies (among the mechanisms) and thresholds (within each mechanism) to define the most likely conditions controlling dike propagation (Acocella and Neri, 2009). To this aim, theoretical and modeling studies should be better tied to natural examples, especially from extinct feeding zones, where available databases should be compared.

\section{CHALLENGE 3: EMPLACEMENT AND OUTCOME OF SHALLOWER INTRUSIONS}

When dikes stall at depth, they may form and/or feed shallow ( $<3 \mathrm{~km}$ depth) magma reservoirs, not necessarily triggering eruptions (e.g., Moran et al., 2011). These shallow intrusions are particularly relevant, as they may often pass undetected by geophysical analysis, but may trigger eruptions with shorter warning time. These intrusions may also remain stalled, producing the geodetic, seismic and geochemical variations characterizing an unrest at the surface. On the longer-term, shallow intrusions have been also suggested to induce resurgence at the surface (Kawakami et al., 2007), providing an additional cause of instability, independently of the deeper magma reservoir. Campi Flegrei caldera, Italy, one of the most dangerous volcanoes on Earth, provides an interesting example

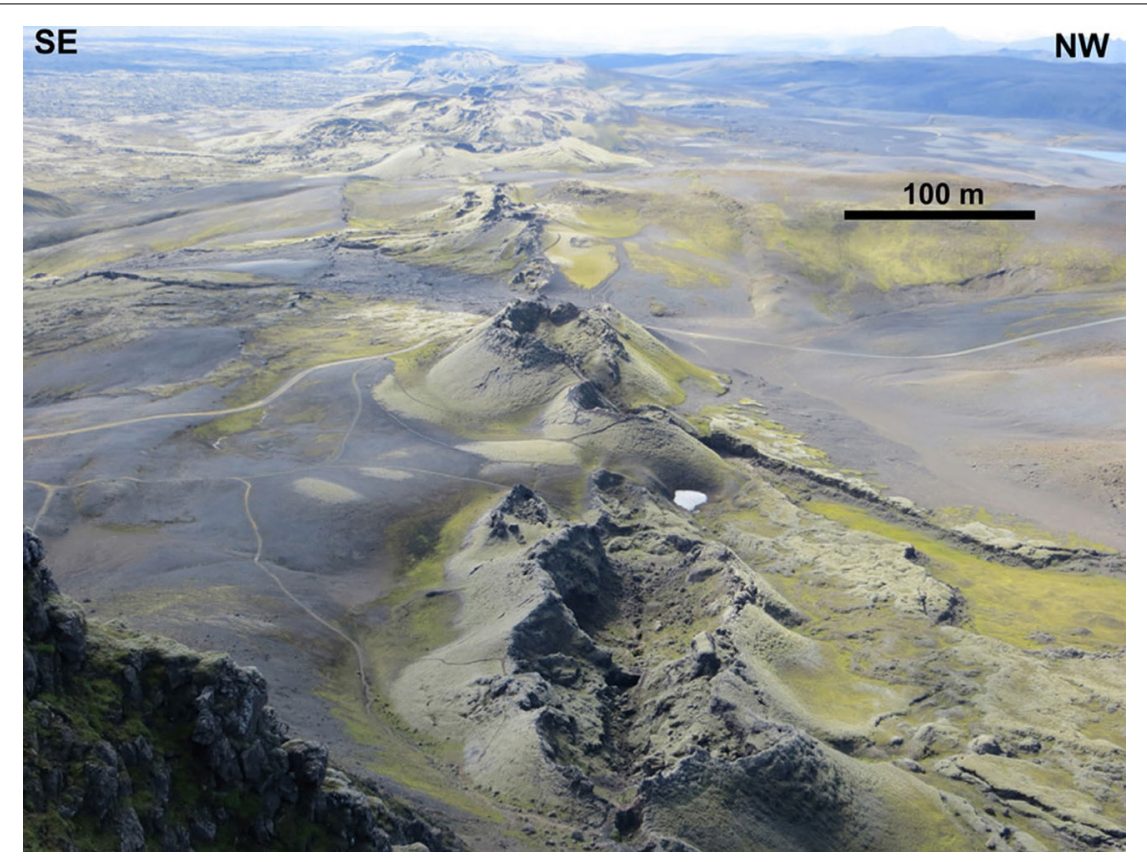

FIGURE 4 | Central portion of the 1783 Lakagigar fissure eruption, Iceland, fed by one or more regional dikes for a total length of $\sim \mathbf{2 5} \mathbf{~} \mathbf{~ m}$. Approximate scale is included for reference. Examples like this highlight the importance of dikes in transferring magma within the crust and in triggering eruptions.

of restless volcano whose recent activity (last eruption in 1538 and successive unrest phases) results from the shallow emplacement of magma (De Siena et al., 2010; Chiodini et al., 2012). Shallow magma emplacement has also triggered large and recent eruptions. For example, a pre-eruptive shallow emplacement has been suggested for the magma responsible for the Novarupta 1912 eruption, Alaska, producing $\sim 30 \mathrm{~km}^{3}$ of ignimbrite (Combs and Gardner, 2001). Therefore, shallower intrusions deserve particular attention for their role on unrest and eruptive episodes. In particular, why should we expect to have accumulation of magma close to the surface, rather than any eruption? Are these intrusions a warranty for the stalling of deeper magma, or rather, are they an important step for the magmas to be erupted? In addition, which are the compositional, petrological, physical and rheological requirements for the magma, and the physical requirements for the host rock, to develop shallow intrusions? May resurgence be commonly explained by shallow intrusions, or is this a process more typically occurring within deeper magma reservoirs?

On the one side, a higher effort should be paid in detecting shallower intrusions, enhancing the resolution of common geophysical techniques, including seismic tomography, cosmic ray muon tomography and magnetotellurics (e.g., Vanorio et al., 2005; Shinoara and Tanaka, 2012; Siniscalchi et al., 2012). On the other side, we should learn more on their causes and conditions of emplacement, as well as their likely fate (freezing vs. erupting). Petrology and geochemical signature on the $\mathrm{P}-\mathrm{T}$ residence time history of these intrusions should be collected to better reconstruct the magmatic history of a volcano (e.g., Scaillet et al., 2008; Cooper and Kent, 2014) and compared in different volcanoes, to detect any common behavior.

\section{CHALLENGE 4: VOLCANO UNREST}

All eruptions are preceded by an unrest phase, which may be highly variable from volcano to volcano and even within the same volcano (Figure 5). However, only a part of the unrest episodes culminates in an eruption (e.g., Moran et al., 2011; Sparks et al., 2012; Phillipson et al., 2013). Therefore, an unrest, being a necessary but not sufficient condition for eruption, is the most intriguing and delicate state of an active volcano. Indeed, understanding unrest episodes is not only important to unravel the behavior and operating 


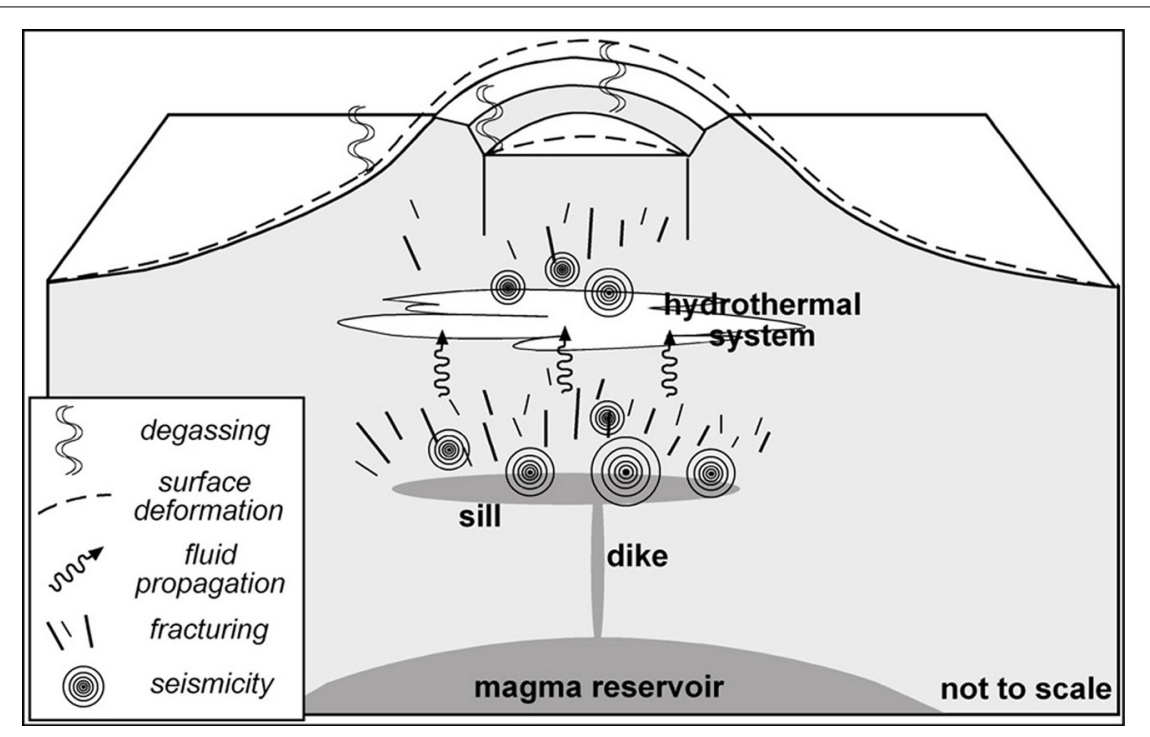

FIGURE 5 | A general process likely responsible for volcano unrest: the emplacement of magma (sill) may induce fracturing and thus variations in the permeability of the host rock, also resulting in fluid migration and, in turn, pressure variation within a hydrothermal system. At the surface, these processes manifest themselves through seismic, deformative, and degassing deviations from the baseline.

principles of a volcano, but also to forecast impending eruptions. Many unrest episodes have been inferred to result, in addition to magma rise and emplacement, from pressurized hydrothermal systems or regional earthquakes (e.g., Newhall and Dzurisin, 1988; Walter et al., 2009; Fournier and Chardot, 2012). As for hydrothermal systems, it is often difficult to distinguish and discriminate their role on an unrest episode, also because of the limited knowledge on their extent, physical and chemical features. However, the possibility that any unrest ultimately has a magmatic origin, where the magma is the essential ingredient, deserves to be further investigated and probably better acknowledged.

Pre-eruptive unrest episodes often show linear behaviors, characterized by the progressive increase in the intensity of one or more unrest indicators detected through the monitoring system, as for example observed at Mount Pinatubo in 1991 (Newhall and Punongbayan, 1996). However, many unrest episodes may be characterized by a non-linear behavior, with important time variations in the intensity of the detected indicators, making any real-time interpretation extremely difficult, as for example recently observed at Rabaul or Okmok calderas (e.g., Biggs et al., 2010; Johnson et al., 2010). Even less is known on the unrest episodes preceding large eruptions and super-eruptions, due to their lower frequency of occurrence and the lack of instrumental detection: in these cases, do we may expect pre-eruptive behaviors similar to those of average-sized eruptions? More in general, to understand active volcanoes and their erupting potential, we should focus our attention on the following questions. Why is a volcano experiencing unrest? What happens during and after unrest, and why? Which is the probability that the unrest anticipates an eruption of certain explosivity, and why?

Despite these uncertainties, a significant though dispersed and fragmented wealth of monitoring data is now available through publications, reports and websites. The collection and systematic and critical review and analysis of such information may provide important insights for identifying general behaviors, establishing patterns, thresholds and relationships and, ultimately understanding unrest processes. Important international initiatives, as WOVODAT (http://www. wovodat.org/), in collecting raw data from unresting volcanoes are trying to respond to this need and should definitely be encouraged.

\section{CHALLENGE 5: ERUPTION FORECASTING}

Forecasting is the crucial challenge of volcanology, as volcanoes are potentially affecting nearly $1 / 10$ of the Earth population. After previous deterministic attempts, forecasting is now being made mainly using a probabilistic approach, also including Bayesian event tree models, which recognize natural variability and stochastic elements, include the full range of possible events and show most likely scenarios (Sparks, 2003; Aspinall et al., 2006; Marzocchi et al., 2008). Forecasting should not be restricted at evaluating only the probability of occurrence of an impeding eruption, but also its expected location, size and style, including the occurrence of ash plumes, which may affect areas very distant from the volcano.

In general, eruption forecast appears less challenging than, say, earthquake forecast, as the approximate location and time of the event may be perceived. Indeed, in several tens of cases, impending eruptions have been successfully forecast, even at poorly monitored volcanoes, saving lives, properties and other values (e.g., McNutt, 2000; Sparks, 2003). However, despite promising efforts (e.g., Wylie et al., 1999; Roman et al., 2006; Aiuppa et al., 2007; Brenguier et al., 2008), there is still a substantial lack of reliable and diagnostic eruptive precursors. This leads to the significant uncertainty of short-term eruption forecasting, especially for the nonnegligible percentage of eruptions with non-linear pre-eruptive behavior. More in general, volcanoes are complex systems controlled by many unknown parameters and prone to sudden failure, so that even minor differences may determine the outcome and some systems may seem or even be inherently unpredictable (e.g., Sparks et al., 2012).

While many unknowns will continue to accompany the unpredictability of unrest episodes, an important effort in forecasting is to identify and focus on at least the more "predictable" part. This may not be immediately recognizable, but it may become so once databases are created, merged and statistically analyzed. Available statistical tools then need to be improved and based on the understanding of how volcanoes work, rather than at simply recognizing longer-term patterns. 
After having been describing processes for decades, we now need to merge this information to understand processes. A crucial input for the understanding of the preeruptive signals required for forecasting will be demanded to advanced physical modeling (e.g., Connor et al., 2003).

\section{CHALLENGE 6: ERUPTING CONDITIONS}

A crucial step within the volcano factory is reached when the magma approaches the eruptive conditions. Several studies have been investigating the conditions and processes for eruptions, including magma mixing, magma rheology, gas behavior, fragmentation, conduit controls, regional earthquakes (e.g., Alidibirov and Dingwell, 1996; Hill et al., 2002; Cashman, 2004; Barnett and Lorig, 2007; Costa et al., 2007; Cooper and Kent, 2014). While important progresses have been made, our knowledge on several of these processes is still largely incomplete and related to specific, isolated or ideal situations. This results in a fragmented understanding of the conditions, factors and thresholds leading to eruptions. For example, there are controversial data on the response of volcanoes to mega-earthquakes along subduction zones. While some studies show an increase in the post-seismic eruptive frequency of magmatic arcs nearby mega-earthquakes, other studies reveal only a moderate post-seismic subsidence of the volcanic edifices (Walter and Amelung, 2007; Takada and Fukushima, 2013). In a similar fashion, the role of magmatic fragmentation on triggering explosive eruptions is also explained by contrasting models; conversely to conventional views, some studies suggest that explosive eruptions are not an inevitable consequence of fragmentation (Papale, 1999; Gonnermann and Manga, 2003). Further on, the channeling of erupting magma passing from a linear feature at depth (a dike) to a punctiform feature at the surface (a vent) has been interpreted as resulting from thermal erosion of the wall rock or different volumetric flow due to layering within the host rock (Holness and Humphreys, 2003; Gudmundsson et al., 2012). These are just some examples, at various scales of observation, on how specific eruptive conditions have been differently interpreted, highlighting our partial knowledge.
To better synthesize these interpretative differences and overcome the knowledge gaps on the processes leading to eruptions we have to improve and extend the boundary conditions of the modeling studies, especially those on fluid mechanics, and tie these with available databases from natural cases. A further and more difficult challenge derives from the fact that these conditions and factors may vary significantly and not have the same importance and priority from case to case; therefore, even though conditions and processes may be reasonably understood in specific and a posteriori ideal cases, we may still not be able to individually detect them in realtime at a volcano prone to erupt.

\section{CHALLENGE 7: COLLAPSING VOLCANOES}

Usually but not always necessarily related to eruptions are the extreme events occurring within the volcanic edifice, resulting in collapses. These may consist of vertical collapses, causing or reactivating calderas, or lateral flank collapses, with very different rates, volumes and modalities. Both vertical and lateral collapses can induce catastrophic variations in the shape of a volcanic edifice, its plumbing system and the environment. Moreover, as both types of collapses may not be necessarily associated to eruptions, they pose a hazard also during periods of apparent inactivity. Many recent studies have allowed understanding several features of these collapses.

Calderas are related to the withdrawal of magma from a reservoir at depth, during an eruption or lateral intrusion. Caldera collapse occurs under specific eruptive conditions and, in the last decades, it has occurred a few times only (Geyer and Martì, 2008; Stix and Kobayashi, 2008; Michon et al., 2011). While caldera collapse is relatively infrequent, it is still difficult to forecast it, as there is uncertainty on its triggering causes and the proper detection of these causes at the surface: in fact, caldera collapse may be triggered by both overpressure or underpressure conditions within a magma chamber, including lateral intrusion of magma, giving the system a wide spectrum of dynamic variability (e.g., Gudmundsson, 1998; Martì et al., 2009). To better constrain this variability, more effort should be given at investigating the magmatic and dynamic conditions within the magma chamber at the onset of caldera collapse.

Lateral collapses are a catastrophic expression of flank instability of volcanic edifices. Similarly to calderas, a significant amount of studies has been conducted on volcano flank instability in the last decades; these studies have highlighted many possible triggering processes, including magma emplacement, hydrothermal alteration, excess pore pressures, volcano and/or basement strength, fault activation and earthquakes. Similarly to calderas, lateral collapses are relatively infrequent. The sudden collapse of an entire sector of a volcano may have a frequency of some decades, as observed at Bezymianny (Kamchatka) in 1956, Mount St. Helens (Oregon) in 1980, and Soufriere Hills (Montserrat) in 1997 (Belousov et al., 2007). However, more localized instabilities occurring on the flank of volcanoes, as observed at Etna and Stromboli in 2002 and 2007, respectively may still be of significant concern to the Civil Defense (Neri and Lanzafame, 2009, and references therein; Acocella and Puglisi, 2013). Similarly to vertical collapses, the variability and problematic detection of the possible triggering factors for lateral collapses make any real-time definition of the conditions and causes of failure difficult.

Therefore, calderas and flank collapses are catastrophic processes characterized by the limited knowledge of the triggering factors, which may vary or be consistent, even for a given volcano. More effort should be given in identifying, for each volcano, the fewest most likely causes of flank instability and focusing the monitoring system at their detection.

\section{CHALLENGE 8: ENVIRONMENTAL IMPACT OF ERUPTIONS}

An erupted magma may emplace on the Earth's surface through very different mechanisms, generating for example lava flows, pyroclastic density currents, ash falls or surge deposits. The knowledge of these mechanisms is essential, in addition to understanding processes, also to assess the impact on the environment, including the impact on humans. For example, several studies have tried to constrain how the flow of a lava depends on the 

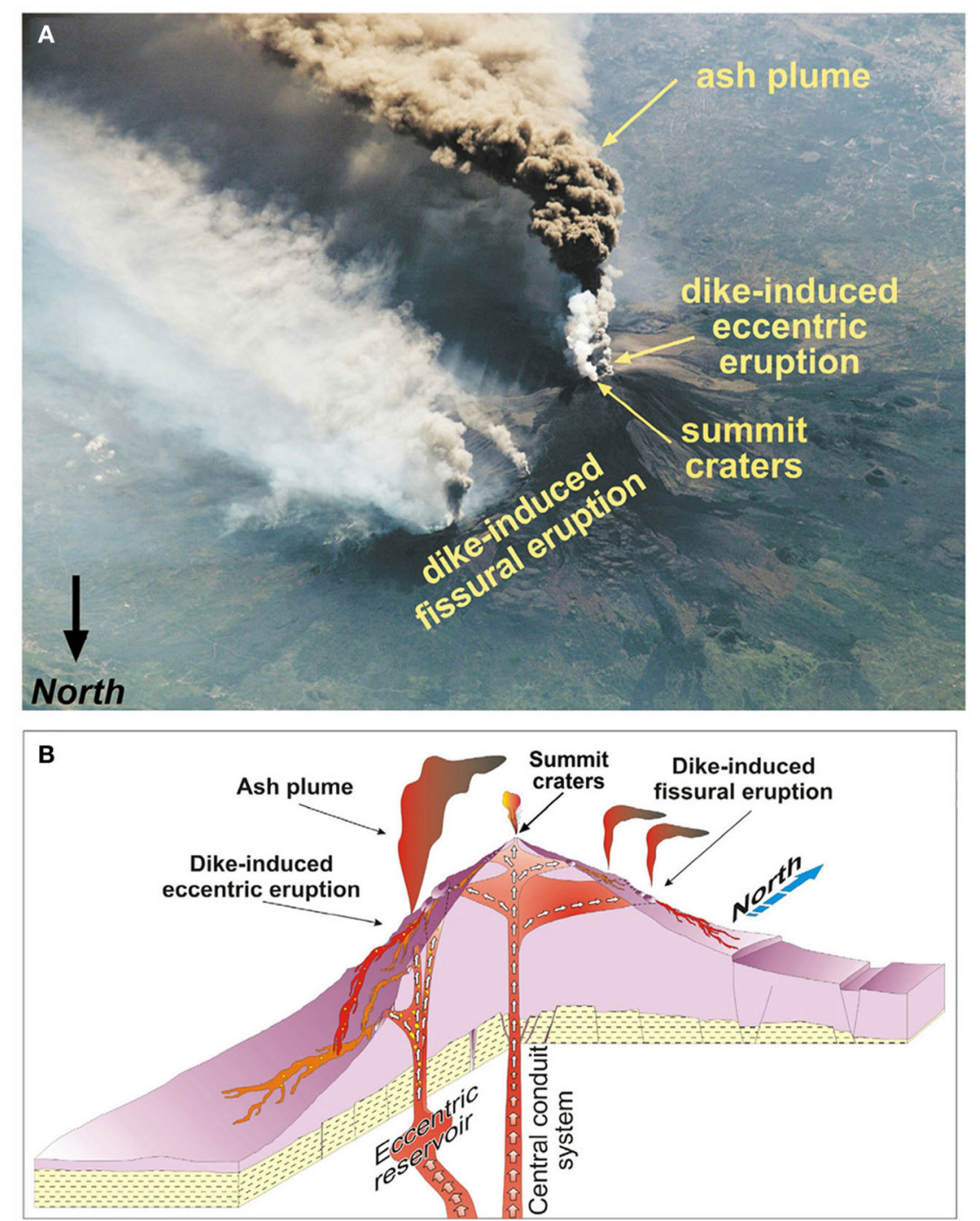

FIGURE 6 | Linking the environmental impact of the vents feeding an eruption to the transfer of magma within a volcano. (A) Shuttle image (property of NASA) of Mt. Etna, Italy, erupting in 2002, activating the summit craters and the NE Rift (erupting degassed magma) and a vent on the $S$ Rift (erupting primitive undegassed magma from the more explosive ash plume). (B) Independent structural interpretation of the eruption, showing how the vent of the S Rift is fed by a dike from an eccentric reservoir external to the summit conduit; conversely, the effusive summit and the NE Rift vents are fed by the residual magma within the summit conduit (Andronico et al., 2005). Note that the direction of the North in the two figures is opposite.

composition and rheology and the underlying topography, or to define the modalities of development and propagation of pyroclastic density currents, or even the dispersion and fall of tephra (e.g., Neri et al., 2003; Webley et al., 2012; Roche et al., 2013). Modeling has been playing a key role in unraveling these processes, even though the need to introduce more realistic constraints is clear, especially for the most complicated emplacement varies widely depending on the type of volcanic activity, but it also assumes a different weight depending on where it happens: even a modest volcanic event can become very relevant if manifested in a densely urbanized area. The study of the impact of volcanic activity on the human health is a very recent but rapidly expanding discipline and ranges from the effects of the exposure to volcanic ash to those of potential contaminants, as for example fluoride and selenium (Allibone et al., 2012; Floor and Roman-Ross, 2012; Hillman et al., 2012). This field, being at its infancy and having significant implications, is bound to become a crucial part of modern volcanology.

The vast majority of eruptions affect the volcano surroundings (distance $<10^{1} \mathrm{~km}$ ). However, a minor part may also affect a much larger area, even the planet. For example, the 2010 Eyiafjallajokull eruption in Iceland showed how a moderately-sized ash plume may impact areas at thousands of $\mathrm{km}$ of distance (Sigmundsson et al., 2010), revealing our unpreparedness to forecast the occurrence of ash plumes. Slightly larger eruptions, as Pinatubo in 1991, may inject a significant amount of sulfurbearing gases into the stratosphere, converting them to sulfate aerosols. These may cool and/or warm the Earth's surface over a few years, affecting global climate. In these cases, for real-time detection of environmental and climatic response, we need to be able to forecast the initial distribution and transport of the emission cloud, as well as the released amount of sulfur impacting the stratosphere (Robock, 2000, 2002; Cole-Dai, 2010). The latter depends, in addition to the explosivity and duration of the eruption, on the sulfur content and solubility in the magma (e.g., Scaillet and Pichavant, 2003; Mysen and Richet, 2005). Current sulfur solubility models are valid within narrow compositional ranges, lacking general applicability and, so far, cannot calculate any gas release in the atmosphere. A general sulfur solubility model for magmas, also allowing constraining sulfur release from impending eruptions, would be needed to evaluate $a$ priori the climatic impact of larger eruptions.

This overview has highlighted the most general and impending challenges 
which Frontiers in Volcanology intends to address with any type of contribution, method and scale of investigation, on Earth and any extraterrestrial body. The list presented here may appear subjective and may result too much broad or, conversely, even incomplete, so that some challenges may be removed and/or other challenges may deserve to be included. While the interests of Frontiers in Volcanology are definitely not restricted to or limited by the presented challenges, it is important to note that these involve very general processes engaging all the disciplines of modern volcanology and, as such, may be of interest for the broadest volcanological community.

These challenges should not be considered as separate entities. Rather, they should be merged in a holistic vision of volcanology, where any progress in a sector impacts other sectors. This important concept is emphasized in Figure 6A, showing a space image of Etna erupting in 2002. More than a splendid image of an eruption, this picture allows us to link our understanding of the shallow plumbing system of the volcano to the environmental impact of an eruption. As visible on the figure, three groups of vents are active. Both the summit craters and the NE Rift erupt residual degassed magma from the open summit conduit (the NE Rift is fed by the summit conduit through a laterally propagating dike); conversely, the vent on the South Rift is fed by an independent vertically propagating dike, filled with new and more primitive undegassed magma (Figure 6B; Andronico et al., 2005). These structural, volcanological and petrological differences are reflected in the eruptive styles shown in Figure 6A; while the plumes from the summit craters and NE Rift show vapor emission with low explosivity, the higher and darker ash plume from the South Rift shows a much higher explosivity. This example underlines the importance of connecting the different aspects of the volcano factory, to provide independent and complimentary information to solve the larger puzzle. Indeed, the ultimate challenge a scientist should face is to capture the bigger picture from his/her studies, delivering robust and useful data, as well as general models of wide applicability, to the community. And this is also the ultimate commitment for Frontiers in Volcanology.

\section{ACKNOWLEDGMENTS}

The Author wishes to thank the two reviewers for their constructive suggestions.

\section{REFERENCES}

Acocella, V., and Neri, M. (2009). Dike propagation in volcanic edifices: overview and possible developments. Tectonophysics 471, 67-77. doi: 10.1016/j.tecto.2008.10.002

Acocella, V., and Puglisi, G. (2013). How to cope with volcano flank instability? Recommending prototypal procedures for Mt. Etna. J. Volcanol. Geotherm. Res. 251, 137-148. doi: 10.1016/j.jvolgeores.2012.06.016

Aiuppa, A., Moretti, R., Federico, C., Giudice, G. Guerrieri, S., Miuzzo, M., et al. (2007). Forecasting Etna eruptions by real-time observation of volcanic gas composition. Geology 35, 1115-1118. doi: $10.1130 /$ G24149A.1

Alidibirov, M., and Dingwell, D. B. (1996). Magma fragmentation by rapid decompression. Nature 380, 146-148. doi: 10.1038/380146a0

Allibone, R., Cronin, S. J., Charley, D. T., Neall, V. E., Stewart, R. B., and Oppenheimer, C. (2012). Dental fluorosis linked to degassing of Ambrym volcano, Vanuatu: a novel exposure pathway. Environ. Geochem. Health 34, 155-170. doi: 10.1007/s10653-010-9338-2

Andronico, D., Branca, S., Calvari, S., Burton, M., Caltabiano, T., Corsaro, R. A., et al. (2005). A multi-disciplinary study of the 2002-03 Etna eruption: insights into a complex plumbing system. Bull. Volcanol. 67, 314-330. doi: 10.1007/s00445004-0372-8

Aoki, Y., Takeo, M., Aoyama, H., Fujimatsu, J., Matsumoto, S., Miyamachi, H., et al. (2009). Pwave velocity structure beneath Asama Volcano, Japan, inferred from active source seismic experiment. J. Volcanol. Geotherm. Res. 187, 272-277. doi: 10.1016/j.jvolgeores.2009.09.004

Aspinall, W. P., Carniel, R., Jaquet, O., Woo, G., and Hincks, T. (2006). Using hidden multistate Markov modelswith multi-parameter volcanic data to provide empirical evidence for alert leel decision-support. J. Volcanol. Geotherm. Res. 153, 112-124. doi: 10.1016/j.jvolgeores.2005. 08.010

Barnett, W. P., and Lorig, L. (2007). A model for stresscontrolled pipe growth. J. Volcanol. Geotherm. Res. 159, 108-125. doi: 10.1016/j.jvolgeores.2006.06.006

Belousov, A., Voight, B., and Belousova, M. (2007). Directed blasts and balst-generated pyroclastic density currents: a comparison of the Bezymianny 1956, mount St Helens 1980 and Soufriere Hills, Montserrat 1997 eruptions and deposits. Bull. Volcanol. 69, 701-740. doi: 10.1007/s00445-0060109-y

Biggs, J., Zhong, L., Fournier, T., and Freymueller, J. T. (2010). Magma flux at Okmok volcano, Alaska, from a joint inversion of continuous GPS, campaign GPS and interferometric synthetic aperture radar. J. Geophys. Res. 115, 401. doi: 10.1029/2010JB007577
Brenguier, F., Shapiro, N. M., Campillo, M., Ferrazzini, V., Duputel, Z., Coutant, O., et al. (2008). Towards forecasting volcanic eruptions using seismic noise. Nat. Geosci. 1, 126-130. doi: 10.1038/ngeo104

Caricchi, L., Burlini, L., Ulmer, P., Gerya, T., Vassalli, M., and Papale, P. (2007). Non-Newtonian rheology of crystal-bearing magmas and implications for magma ascent dynamics. Earth Planet. Sci. Lett. 264, 402-419. doi: 10.1016/j.epsl. 2007.09.032

Cashman, K. V. (2004). "Volatile controls on magma ascent and eruption," in The State of the Planet: Frontiers and Challenges in Geophysics: Geophysical Monograph 150, eds R. S. J. Sparks and C. J. Hawkesworth (Washington, DC: American Geophysical Union), 109-124. doi: 10.1029/150GM10

Cashman, K. V., and Sparks, R. S. J. (2013). How volcanoes work: a 25 year perspective. Geol. Soc. Am. Bull. 125, 664-690. doi: 10.1130/B30720.1

Castro, J. M., and Dingwell, D. B. (2009). Rapid ascent of rhyolitic magma at Chaiten volcano, Chile. Nature 461, 780-784. doi: 10.1038/nature 08458

Cayol, V., Dieterich, J., Okamure, A. T., and Miklius, A. (2000). High magma storage rats before the 1983 eruption of Kilauea, Hawaii. Science 288, 2343-2346. doi: 10.1126/science.288.5475. 2343

Chiodini, G., Caliro, S., De Martino, R., Avino, R., and Gherardi, F. (2012). Early signals of new volcanic unrest at campi Flegrei caldera? Insights from geochemical data and physical simulations. Geology 40, 943-946. doi: 10.1130/ G33251.1

Cole-Dai, J. (2010). Volcanoes and Climate. J. Wiley \& Sons. doi: 10.1002/wcc.76

Collins, S. J., Pyle, D., and Maclennan, J. (2009). Melt inclusions track pre-eruption storage and dehydration of magma at Etna. Geology 37, 571-574. doi: 10.1130/G30040A.1

Combs, M. L., and Gardner, J. E. (2001). Shallow storage conditions for the rhyolite of the 1912 eruption at Novarupta, Alaska. Geology 29, 775-778. doi: 10.1130/0091-7613(2001)029\%3C0775:SSCFTR\% 3E2.0.CO;2

Connor, C. B., Sparks, R. S. J., Mason, R. M., Bonadonna, C., and Young, S. R. (2003). Exploring links between physical and probabilistic models of volcanic eruptions: the Souriere Hills Volcano, Montserrat. Geophys. Res. Lett. 30, 1701. doi: 10.1029/2003GL017384

Cooper, K. M., and Kent, A. J. R. (2014). Rapid remobilization of magmatic crystals kept in cold storage. Nature 506, 480-483. doi: 10.1038/nature 12991

Corsaro, R. A., Di Renzo, V., Di Stefano, S., Miraglia, L., and Civetta, L. (2013). Relationship between petrologic processes in the plumbing system of Mt. Etna and the dynamics of the eastern flank from 1995 to 2005. J. Volcanol. Geotherm. Res. 251, 75-89. doi: 10.1016/j.jvolgeores.2012. 02.010

Costa, A., Melnik, O., and Sparks, R. S. J. (2007). Controls of conduit geometry and wallrock elasticity on lava dome eruptions. Earth Planet. Sci. Lett. 260, 137-151. doi: 10.1016/j.epsl.2007. 05.024 
De Siena, L., Del Pezzo, E., and Bianco, F. (2010). Seismic attenuation imaging of Campi Flegrei: evidence of gas reservoirs, hydrothermal basins and feeding system. J. Geophys. Res. 115, B09312. doi: 10.1029/2009JB006938

Druitt, T. H., Costa, F., Deloule, E., Dungan, M., and Scaillet, B. (2012). Decadal to monthly timescales of magma transfer and reservoir growth at a caldera volcano. Nature 482, 77-80. doi: 10.1038/nature10706

Famin, V., and Michon, L. (2010). Volcano destabilization by magma injections in a detachment. Geology 38, 219-222. doi: 10.1130/G30717.1

Floor, G. H., and Roman-Ross, G. (2012). Selenium in volcanic environments: a review. Appl. Geochem. 27, 517-531. doi: 10.1016/j.apgeochem.2011. 11.010

Fournier, N., and Chardot, L. (2012). Understanding volcano hydrothermal unrest from geodetic observations: insights from numerical modeling and application to White Island volcano, New Zealand. J. Geophys. Res. 117, B11208. doi: 10.1029/2012JB009469

Gardine, M., West, M. E., and Cox, T. (2011). Dike emplacement near Parícutin volcano, Mexico in 2006. Bull. Volcanol. 73, 123-132. doi: 10.1007/s00445-010-0437-9

Geshi, N., Kusumoto, S., and Gudmundsson, A. (2010). Geometric difference between non-feeder and feeder dikes. Geology 38, 195-198. doi: 10.1130/G30350.1

Geyer, A., and Martì, J. (2008). The new worldwide collapse caldera database (CCDB): a tool for studying and understanding caldera processes. J. Volcanol. Geotherm. Res. 175, 334-354. doi: 10.1016/j.jvolgeores.2008.03.017

Gonnermann, H. M., and Manga, M. (2003). Explosive volcanism may not be an inevitable consequence of magma fragmentation. Nature 426, 432-435. doi: 10.1038/nature02138

Gravley, D. M., Wilson, C. J. N., Leonard, G. S., and Cole, J. W. (2007). Double trouble: paired ignimbrite eruptions and collateral subsidence in the Taupo Volcanic Zone, New Zealand. Geol. Soc. Am. Bull. 119, 18-30. doi: 10.1130/B25924.1

Gudmundsson, A. (1998). Formation and development of normal fault calderas and the initiation of large explosive eruptions. Bull. Volcanol. 60, 160-170. doi: 10.1007/s004450050224

Gudmundsson, A. (2006). How local stresses control magma-chamber ruptures, dyke injections, and eruptions in composite volcanoes. Earth Sci. Rev. 79, 1-31. doi: 10.1016/j.earscirev.2006. 06.006

Gudmundsson, A. (2011). Rock Fractures in Geological Processes. Cambridge University Press. doi: 10.1017/CBO9780511975684

Gudmundsson, A., Kusumoto, S., Simmenes, T., Philipp, S., Larsen, B., and Lotveit, I. F. (2012). Effects of overpressure variations on fracture apertures and fluid transport. Tectonophysics 581, 220-230. doi: 10.1016/j.tecto.2012.05.003

Hill, D. P., Pollitz, F., and Newhall, C. (2002). Earthquake-volcano interactions. Phys. Today 55, 41-47. doi: 10.1063/1.1535006

Hillman, S. E., Horwell, C. J., Densmore, A. L., Damby, D. E., Fubini, B., Ishimine, Y., et al. (2012). Sakurajima volcano: a physico-chemical study of the health consequences of long-term exposure to volcanic ash. Bull. Volcanol. 74, 913-930. doi: 10.1007/s00445-012-0575-3

Holness, M. B., and Humphreys, M. C. S. (2003). The Traigh Bhàn na Sgurra Sill, Isle of Mull: flow localization in a major magma conduit. J. Petrol. 44, 1961-1976. doi: 10.1093/petrology/egg066

Johnson, R. W., Itikarai, I., Patia, H., and McKee, C. O. (2010). "Volcanic systems of the northeastern Gazelle Peninsula, Papua new guinea: synopsis, evaluation and a model for Rabaul volcano," in Rabaul Volcano Workshop Report, 94.

Kavanagh, J. L., Menand, T., and Sparks, R. S. J. (2006). An experimental investigation of sill formation and propagation in layered elastic media. Earth Planet. Sci. Lett. 245, 799-813. doi 10.1016/j.epsl.2006.03.025

Kawakami, Y., Hoshi, H., and Yamaguchi, Y. (2007). Mechanism of caldera collapse and resurgence: observations from the northern part of the Kumano Acidic Rocks, Kii peninsula, southwest Japan. J. Volcanol. Geotherm. Res. 167, 263-281. doi: 10.1016/j.jvolgeores.2007. 02.003

Kennedy, B., Wilcox, J., and Stix, J. (2012). Caldera resurgence during magma replenishment and rejuvenation at Valles and lake City calderas. Bull. Volcanol. 74, 1833-1847. doi: 10.1007/s00445-0120641-X

Leuthold, J., Montener, O., Baumgartner, L., Putlitz, B., Ovtcharova, M., and Schaltegger, U. (2012). Time resolved construction of a bimodal laccolith (Torres del Paine, Patagonia). Earth Planet. Sci. Lett. 325, 85-92. doi: 10.1016/j.epsl.2012.01.032

Lowenstern, J. B., Smith, R. B., and Hill, D. P. (2006). Monitoring super-volcanoes: geophysical and geochemical signals at Yellowstone and other large caldera systems. Philos. Trans. R. Soc. 364, 2055-2072. doi: 10.1098/rsta.2006.1813

Maccaferri, F., Rivalta, E., Keir,D., and Acocella, A. (2014). Unloading-driven off-rift distribution of volcanism in rift zones. Nat. Geosci. 7, 297-300. doi: $10.1038 /$ ngeo 2110

Martì, J., Geyer, A., and Folch, A. (2009). A Genetic Classification of Collapse Calderas Based on Field Studies, and Analogue and Theoretical Modelling. London: Geological Society of London Spec. Publ. 2.

Marzocchi, W., Sandri, L., and Selva, J. (2008). BET_EF: a probabilistic tool for long-and shortterm eruption forecasting. Bull. Volcanol. 70, 623-632. doi: 10.1007/s00445-007-0157-y

McNutt, S. R. (2000). "Seismic monitoring," in Encyclopedia of Volcanoes, ed H. Sigurdsson (Academic Press), 1095-1120.

Merle, O., Brothelande, E., Lenat, J. F., Bachelery, P., and Garaebity, E. (2013). A structural outline of the Yenkahe volcanic resurgent dome (Tanna Island, Vanuatu Arc, South Pacific). J. Volcanol. Geotherm. Res. 268, 64-72. doi: 10.1016/j.jvolgeores.2013.10.009

Michon, L., Massin, F., Famin, V., Ferrazzini, V., and Roult, G. (2011). Basaltic calderas: collapse dynamics, edifice deformation, and variations of magma withdrawal. J. Geophys. Res. 116, B03209. doi: 10.1029/2010JB007636

Moran, S., Newhall, C., and Roman, D. C. (2011). Failed magmatic eruptions: late-stage cessation of magma. Bull. Volcanol. 73, 115-122. doi: 10.1007/s00445-010-0444-x
Mysen, B. O., and Richet, P. (2005). Silicate Glasses and Melts, Properties and Structure. Amsterdam: Elsevier.

Neri, A., Esposti Ongaro, T., Macedonio, G., and Gidaspow, D. (2003). Multiparticle simulation of collapsing volcanic columns and pyroclastic flow. J. Geophys. Res. 108, 2202. doi: 10.1029/2001JB000508

Neri, M., and Lanzafame, G. (2009). Structural features of the 2007 Stromboli eruption. J. Volcanol. Geotherm. Res. 182, 137-144. doi: 10.1016/j.jvolgeores.2008.07.021

Newhall, C. G., and Dzurisin, D. (1988). Historical Unrest at Large Calderas of the World. Vancouver, WA: U.S. Geological Survey.

Newhall, C. G., and Punongbayan, R. S. (1996). Fire and Mud: Eruptions and Lahars of Mount Pinatubo, Philippines. Hong Kong: University of Washington Press.

Papale, P. (1999). Strain-induced magma fragmentation in explosive eruptions. Nature 397, 425-428. doi: $10.1038 / 17109$

Parks, M. M., Biggs, J., England, P., Mather, T. A., Nomikou, P., Palamartchouk, K., et al. (2012). Evolution of Santorini Volcano dominated by episodic and rapid fluxed of melt from depth. Nat. Geosci. 5, 749-754. doi: 10.1038/ ngeo1562

Phillipson, G., Sobradelo, R., and Gottsmann, J. (2013). Global volcanic unrest in the $21 \mathrm{st}$ century: an analysis of the first decade. J. Volcanol. Geotherm. Res. 264, 183-196. doi: 10.1016/j.jvolgeores.2013.08.004

Pinel, V., and Jaupart, C. (2004). Likelihood of basaltic eruptions as a function of volatile content and volcanic edifice size J. Volcanol. Geotherm. Res. 137, 201-217. doi: 10.1016/j.jvolgeores.2004.05.010

Robock, A. (2000). Volcanic eruptions and climate. Rev. Geophys. 38, 191-219. doi: 10.1029/1998RG000054

Robock, A. (2002). The climatic aftermath. Science 295, 1242-1244. doi: 10.1126/science. 1069903

Roche, O., Nino, Y., Mangeney, A., Brand, B., Pollock, N., and Valentine, G. A. (2013). Dynamic porepressure variations induce substrate erosion by pyroclastic flows. Geology 41, 1107-1110. doi: 10.1130/G34668.1

Roman, D. C., Neuberg, J., and Luckett, R. R. (2006). Assessing the likelihood of volcanic eruption through analysis of volcanotectonic earthquake fault-plan solutions. Earth Planet. Sci. Lett. 248, 244-252. doi: 10.1016/j.epsl.2006.05.029

Ruch, J., Acocella, V., Geshi, N., Nobile, A., and Corbi, F. (2012). Kinematic analysis of vertical collapse on volcanoes using experimental models time series. J. Geophys. Res. 117, B07301. doi:10.1029/2012JB009229

Ruprecht, P., and Plank, T. (2013). Feeding andesitic eruptions with a high-speed connection from the mantle. Nature 500, 68-72. doi: $10.1038 /$ nature 12342

Sakuma, S., Kajiwara, T., Nakada, S., Uto, K., and Shimizu, H. (2008). Drilling and logging results of USDP-4-Penetration into the volcanic conduit of Unzen Volcano, Japan. J. Volcanol. Geotherm. Res. 175, 1-12. doi: 10.1016/j.jvolgeores.2008. 03.039 
Saunders, A. (2005). Large igneous provinces: origin and environmental consequences. Elements 1, 259-263. doi: 10.2113/gselements.1.5.259

Scaillet, B., and Pichavant, M. (2003). "Experimental constraints on volatile abundances in arc magmas and their implications for degassing processes," in Volcanic Degassing, eds C. Oppenheimer, D. Pyle, and J. Barclay (Geological Society London Special Publications), 23-52. doi: 10.1144/GSL.SP.2003.213.01.03

Scaillet, B., Pichavant, M., and Cioni, R. (2008). Upward migration of Vesuvius magma chamber over the past 20,000 years. Nature 455, 216-219. doi: $10.1038 /$ nature 07232

Shinoara, H., and Tanaka, H. K. M. (2012). Conduit magma convection of a rhyolitic magma: constraints from cosmic-ray muon tomography of Iwodake, Satsuma-Iwojima volcano, Japan. Earth Planet. Sci. Lett. 349, 87-97. doi: 10.1016/j.epsl.2012.07.002

Sigmundsson, F., Hreinsdottir, S., Hooper, A., Arnadottir, T., Pedersen, R., Roberts, M. J., et al. (2010). Intrusion triggering of the 2010 Eyjafjallajokull explosive eruption. Nature 468, 426-430. doi: 10.1038/nature09558

Siniscalchi, A., Tripaldi, S., Neri, M., Balasco, M., Romano, G., Ruch, J., et al. (2012). Flank instability structure of Mt. Etna inferred by a magnetotelluric survey. J. Geophys. Res. 117, B03216. doi: 10.1029/2011JB008657

Sparks, R. S. J. (2003). Forecasting volcanic eruptions. Earth Planet. Sci. Lett. 210, 1-15. doi: 10.1016/S0012-821X(03)00124-9

Sparks, R. S. J., Biggs, J., and Neuberg, J. W. (2012). Monitoring volcanoes. Science 335, 1310-1311. doi: 10.1126/science. 1219485

Stix, J., and Kobayashi, T. (2008). Magma dynamics and collapse mechanisms during four historic caldera-forming events. J. Geophys. Res. 113, B09205. doi: 10.1029/2007JB005073

Taisne, B., Tait, S., and Jaupart, C. (2011). Conditions for the arrest of a vertical propagating dyke. Bull.
Volcanol. 73, 191-204. doi: 10.1007/s00445-0100440-1

Takada, Y., and Fukushima, Y. (2013). Volcanic subsidence triggered by the 2011 Tohoku earthquake in Japan. Nat. Geosci. 6, 637-641. doi: $10.1038 /$ ngeo 1857

Thordarson, T., and Larsen, G. (2007). Volcanism in historical time: volcano types, eruptions styles and eruptive history. J. Geodyn. 43, 118-152. doi: 10.1016/j.jog.2006.09.005

Valentine, G. A., and Krogh, K. E. C. (2006). Emplacement of shallow dikes and sills beneath a small basaltic volcanic center-the role of preexisting structure (Paiute Ridge, southern Nevada, USA). Earth Planet. Sci. Lett. 246, 217-230. doi: 10.1016/j.epsl.2006.04.031

Vanorio, T., Virieux, J., Capuano, P., and Russo, G. (2005). Three dimensional seismic tomography from $\mathrm{P}$ wave and $\mathrm{S}$ wave microearthquake travel times and rock physics characterization of the Campi Flegrei Caldera. J. Geophys. Res. 110, B03201. doi: 10.1029/2004JB003102

Vazquez, J. A., and Reid, M. R. (2004). Probing the accumulation history of the Voluminous Toba Magma. Science 305, 991-994. doi: 10.1126/science. 1096994

Vezzoli, L., Principe, C., Malfatti, J., Arrighi, S., Tanguy, J. C., and Le Goff, M. (2009). Modes and times of caldera resurgence: the $<10 \mathrm{ka}$ evolution of Ischia caldera, Italy, from high precision archaeomagnetic dating. J. Volcanol. Geotherm. Res. 186, 305-319. doi: 10.1016/j.jvolgeores.2009.07.008

Walter, T. R., and Amelung, F. (2007). Volcanic eruptions following M9 megathrust earthquakes: implications for the Sumatra-Andaman volcanoes. Geology 35, 539-542. doi: 10.1130/ G23429A.1

Walter, T. R., Wang, R., Acocella, V., Neri, M., Grosser, H., and Zschau, J. (2009). Simultaneous magma and gas eruptions at three volcanoes in southern Italy: an earthquake trigger? Geology 37, 251-254. doi: 10.1130/ G25396A

Webley, P. W., Steensen, T., Stuefer, M., Grell, G., Freitas, S., and Pavolonis, M. (2012). Analyzing the Eyjafjallajokull 2010 eruption using satellite remote sensing, lidar and WRF-Chem dispersion and tracking model. J. Geophys. Res. Atmos. 117, D00U26. doi: 10.1029/201 1JD016817

Wilson, C. J. N., and Charlier, B. L. A. (2009). Rapid rates of magma generation at contemporaneous magma systems, Taupo volcano, New Zealand: insights from U-Th model-age spectra in zircons. J. Petrol. 50, 875-907. doi: 10.1093/petrology/egp023

Wylie, J. J., Voight, B., and Whitehead, J. A. (1999). Instability of magma flow from volatile-dependent viscosity. Science 285, 1883-1885. doi: $10.1126 /$ science.285.5435.1883

Conflict of Interest Statement: The author declares that the research was conducted in the absence of any commercial or financial relationships that could be construed as a potential conflict of interest.

Received: 26 February 2014; accepted: 20 March 2014; published online: 21 April 2014.

Citation: Acocella V (2014) Great challenges in volcanology: how does the volcano factory work? Front. Earth Sci. 2:4. doi: 10.3389/feart.2014.00004

This article was submitted to Volcanology, a section of the journal Frontiers in Earth Science.

Copyright (c) 2014 Acocella. This is an open-access article distributed under the terms of the Creative Commons Attribution License (CC BY). The use, distribution or reproduction in other forums is permitted, provided the original author(s) or licensor are credited and that the original publication in this journal is cited, in accordance with accepted academic practice. No use, distribution or reproduction is permitted which does not comply with these terms. 